\title{
Asthma diagnosis and treatment - 1013. Six month follow up on pediatric patients with severe persistent allergic asthma after on eyear of omalizumb therapy
}

\author{
Tarun Choudhuri \\ From 2nd WAO International Scientific Conference (WISC 2012) \\ Hyderabad, India. 6-9 December 2012
}

\section{Purpose}

Anti-IgE antibody had been used in severe persistent allergic asthma in adults. However, its long-term efficacy in pediatric patients in India has not been reported.

\section{Method}

20 pediatric (12 male and 8 female) patients, with mean age of 8.5 having severe persistent allergic asthma, with recurrent exacerbations and on oral/IV steroids, prospectively received Omalizumab $150 \mathrm{mg} / 300 \mathrm{mg}$, depending on $\operatorname{IgE} \&$ body weight for 6 month to 1 year,at B.R.Singh Hospital, Kolkata. Number of exacerbations, total dose of oral Steroids, use of rescue medications, ICS/LABA dose used were recorded at the baseline, 24 weeks, end of treatment and on 6 month follow up (between February 2011 and August 2012) and statistically analyzed.

\section{Results}

All 20 patients after anti-IgE therapy were followed-up for 6 months.Significant reductions observed in total oral steroid use by six months $-15.5 \mathrm{mg}(27.5 \mathrm{mg}$ vs. $12 \mathrm{mg}$; $95 \% \mathrm{CI}, p<0.001)$. Use of rescue medications with $\beta 2$ agonists inhalerdecreased by -7.90 puffs (12.0 vs 4.10 puffs; $95 \% \mathrm{CI}$, p-value $<0.001)$ at 24 weeks and by -13.67 puffs (13.67 vs 0.00 puffs; $95 \% \mathrm{CI}$, p-value $<0.001$ ) at 52 weeks $(\mathrm{n}=6)$. There was significant reduction in ICS dose at week 24 by $-287.50 \mathrm{mcg}$ ( 550.0 vs $262.50 \mathrm{mcg}$; $95 \% \mathrm{CI}$, $\mathrm{p}$-value $<0.001)$. By week $52(\mathrm{n}=6)$ ICS dose further declined to $-458.33 \mathrm{mcg}$ (750.0 vs $291.67 \mathrm{mcg}$; $95 \% \mathrm{CI}$, p-value $<0.001) .15(75 \%)$ patients had severe asthma symptoms at baseline, which came down to $6(30 \%)$

Pediatrics, Fiap, Kolkata, India $(p<0.05)$, at week 24 . Similarly $15(75 \%)$ patients had unscheduled hospitalization at baseline, this figure came down to zero by week 24 .

\section{Conclusion}

Use of anti-IgE antibody for 6 months to 1 year is well tolerated and led to overall significant improvement and stabilization of pediatric patients with severe persistent allergic asthma which was maintained at 6 months post treatment follow-up period.

Published: 23 April 2013

doi:10.1186/1939-4551-6-S1-P13

Cite this article as: Choudhuri: Asthma diagnosis and treatment - 1013.

Six month follow up on pediatric patients with severe persistent allergic asthma after on eyear of omalizumb therapy. World Allergy

Organization Journal 2013 6(Suppl 1):P13.

Submit your next manuscript to BioMed Central and take full advantage of:

- Convenient online submission

- Thorough peer review

- No space constraints or color figure charges

- Immediate publication on acceptance

- Inclusion in PubMed, CAS, Scopus and Google Scholar

- Research which is freely available for redistribution

Submit your manuscript at www.biomedcentral.com/submit () Biomed Central 